\title{
Mimarlık Fakültesi Öğrencilerinin Ekolojik Ayak İzi Farkındalık Düzeyi
}

\author{
Şehriban ERASLAN ${ }^{* 1}$ (1) Destan SEÇME² \\ ${ }^{1}$ Süleyman Demirel Üniversitesi, Mimarlık Fakültesi, Peyzaj Mimarlığı Bölümü, 32260, Isparta, Türkiye \\ 2Pamukkale Belediyesi, Park ve Bahçeler Müdürlüğü, 20150, Denizli, Türkiye
}

(Alınış / Received: 28.09.2020, Kabul / Accepted: 11.09.2021, Online Yayınlanma / Published Online: 25.12.2021)

\author{
Anahtar Kelimeler \\ Ekolojik ayak izi, \\ Farkındalık, \\ Sürdürülebilirlik, \\ Mimarlık fakültesi
}

\begin{abstract}
Özet: Bu çalıșmanın amacı Süleyman Demirel Üniversitesi Mimarlık Fakültesi öğrencilerinin ekolojik ayak izi (EAİ) farkındalık düzeylerinin belirlenmesi ve değerlendirilmesidir. Araştırma 2019 yllı bahar döneminde Süleyman Demirel Üniversitesi Mimarlık Fakültesi'nde öğrenim gören 433 öğrenci ile yürütülmüştür. Araştırmanın değişkenleri; cinsiyet, sınıf düzeyi, en uzun süre yaşanılan yerleșim birimidir. Araştırmada nicel veriler "Ekolojik Ayak İzi Farkındalık Ölçeği" ile toplanmış ve SPSS (Statictical Package for Social Sciences Program) 23.0 paket programı ile analiz edilmiştir. Nicel verilerin analizinde betimsel istatistik teknikleri, bağımsız örneklemler t-testi, tek faktörlü ANOVA ve korelasyon analizinden yararlanılmıștır.

Elde edilen sonuçlara göre; peyzaj mimarlığı, mimarlık ve şehir ve bölge planlama bölümlerinin ekolojik ayak izi (EAI) farkındalık değerleri birbirine çok yakın bulunmuştur. Ekolojik ayak izi (EAİ), gıda ile ulaşım ve barınma boyutunda Peyzaj Mimarlığında okuyan öğrencilerin puanları diğerlerinden yüksek iken enerji ve atık boyutlarında ise Şehir ve Bölge Planlama bölümünde okuyan öğrencilerin puanları diğerlerinden yüksek olduğu görülmüştür.
\end{abstract}

\section{Awareness Level of the Faculty of Architecture Students' Ecological Footprint}

\section{Keywords}

Ecological footprint,

Awareness,

Sustainability,

Faculty of architecture

\begin{abstract}
The aim of this study is to determine and evaluate the ecological footprint awareness (EFA) levels of Süleyman Demirel University Faculty of Architecture students. The research was carried out with 433 students studying at Süleyman Demirel University Faculty of Architecture in the spring term of 2018-2019 academic year. The variables of the research are; gender, class level, the longest lived settlement. Quantitative data were collected with "Ecological Footprint Awareness Scale" ve and analyzed with SPSS (Statistical Package for Social Sciences Program) 23.0 package program. In the analysis of quantitative data, descriptive statistical techniques, independent samples t-test, single-factor ANOVA and correlation analysis were used.

According to the obtained results; The ecological footprint awareness (EFA) values of landscape architecture, architecture and urban and regional planning departments have been found to be very close to each other. In the ecological footprint,(EFA) food and transportation and housing dimension, the scores of those who study in landscape architecture are higher than the others, whereas scores of those who study in urban and regional planning are higher in terms of energy and waste.
\end{abstract}

\section{Giriş}

İnsanoğlunun doğayla birlikteliği, varolduğu andan itibaren başlamıştır. Günümüze kadar doğal kaynakların sınırsızca kullanılması, dünya nüfusunun hızla artması ve bunun sonucu olarak oluşan plansız kentleşme ile global çevre sorunları ortaya çıkmıştır.
Hava, su ve toprak bozunması, küresel rekabet, artan nüfus, teknoloji ve sanayi alanında ilerlemeler, bilinçsiz yaşam şekli doğanın bozulmasına neden olmuştur. Tüm bunların birikimiyle çok farklı çevre sorunları ortaya çıkmış ve bu durum ekosistemin taşıma kapasitesini tehdit etmeye başlamıştır. 
Yaşam döngüsünde birçok doğal kaynak kullanılmakta ve bununla beraber atıkları da oluşmaktadır. İnsanoğlu dünyaya geldiği andan itibaren yaşam ortamını oluşturan tüm doğal kaynakları (su, toprak ve hava) kullanmaktadır. Bununla beraber birçok canlıyı da iradesi doğrultusunda tüketmekte ve onlardan yararlanmaktadır [1]. Üretilen her atık ve kullanılan her kaynak için toprak ve su kirletilmektedir. Bu doğrultuda kullanılan kaynakların üretilmesini sağlamak ve oluşan atıkların yok edilmesi için gerekli olan, biyolojik verimli toprak ve su alanına "ekolojik ayak izi"denir [2,3].

Ekolojik ayak izi, birçok alan ve farklı gruplar üzerinde ölçülebilmektedir. Bu çalışma ekolojik alt yapıya ve farkındalığa sahip Mimarlık Fakültesi öğrencileri ile yapılmıștır. Bu kapsamda SDÜ bünyesinde Mimarlık Fakültesi öğrencilerinin ekolojik ayak izi farkındalık düzeyleri belirlenmiş ve değerlendirilmiştir. Peyzaj Mimarlığı, Mimarlık, Şehir ve Bölge Planlama bölümü öğrencilerinin, çevre bilgilerini ve ekolojik ayak izi farkındalığını belirlemede uzun süre yaşadıkları yerleşim birimi, sınıf ve cinsiyet değişkenlerine bağlı olarak nicel veriler 46 soruluk "Ekolojik Ayak İzi Farkındalık Ölçeği” ile değerlendirilmiştir. Bu ölçek enerji (15 madde), ulaşım ve barınma (9 madde), atıklar ( 9 madde), gıda ( 8 madde) ve su tüketimi (5 madde) olmak üzere 5 alt boyuttan oluşmaktadır. SPSS 23.0 paket programı ile veriler değerlendirilmiş ve analiz edilmiștir. Nicel verilerin analizinde korelasyon analizi, tek faktörlü ANOVA, t-testi, betimsel istatistik teknikleri kullanılmıştır. $\mathrm{Bu}$ kapsamda çalışmanın ana verilerini elde etmek için Ekolojik Ayak İzi Farkındalık Ölçeği [4] kullanılmış ve aşağıdaki araştırma sorularına cevap aranmıştır:

1. Genel olarak öğrencilerin çevresel davranış amaçları nelerdir?

2. Yeme-içme alışkanlıkları nasıldır ve hangi yollarla sağlamaktadır?

3. Ulaşım öncelikleri ve olanakları nelerdir?

4. Barınma tercihleri ve şekilleri nasıldır?

5. Su tüketimi ve alışkanlıkları nasıldır?

6. Tasarruf yöntemlerinin farkında mıdır ve uygular mi?

7. Atık yönetimi hakkında bilgi ve deneyimi nasıldır?

\section{Materyal ve Metot}

\subsection{Araştırma Deseni}

İlișkisel tarama modeli kullanılarak araştırmanın deseni oluşturulmuştur. Bu model, iki ve daha çok değişken arasında beraber değişim özelliği ve derecesini belirleyen araştırma modelidir.

\section{2 Örneklem ve Evren}

SDÜ Mimarlık Fakültesi Şehir ve Bölge Planlama, Peyzaj Mimarlığı, Mimarlık Bölümü (2019 Bahar
Dönemi 1-2-3-4. sınıf) öğrencileri araştırmanın evrenini oluşturmaktadır. 902 öğrencinin(416 Mimarlık, 262'si ŞBP, 224 PM) öğrenim görmekte olduğu Öğrencilerden 433'üne ulaşılmış ve ölçme aracı "Farkındalık Ölçeği" her birine dağıtılmıştır.

\subsection{Veri Toplama Araçları}

Çalışma kapsamında ekolojik bilinç düzeylerinin yüksek olduğu düşünülen SDÜ Mimarlık Fakültesi öğrencilerinin ekolojik ayak izi farkındalığı ölçülmüştür. Araștırmanın değişkenleri; uzun süre yaşadıkları yerleşim birimi, sınıf ve cinsiyet ve öğrenim gördükleri bölümdür.

\subsection{Veri Toplama Süreci}

Çalışma 2019 yılında gerçekleştirilmiştir. Araştırmacı ögrencilerin ders saatlerine göre uygulamasını yürütmüştür. Uygulama süresince araştırmacı öğrencilere çalışmanın hedefi ve farkındalık ölçeği hakkında ön bilgi vermiștir. Ölçeklerin doldurulması için Araştırmacı tarafından dağıtılan formlar $30 \mathrm{dk}$. süre verilmiş ve ölçekler devamında toplanmıştır.

Ölçek içerisinde katılımcılara ait demografik bilgilerin bulunduğu içerik ve bilgi formu olmak üzere iki ayrı veri toplama şekli kullanılmıștır. Ana veriler için Ekolojik Ayak İzi Farkındalık Ölçeği de uygulatılmış ve toplanmıştır [4].

\subsection{Veri Analizi}

Ölçeğin ilk bölümünde demografik özelliklerin bulunduğu 5 soru vardır. Ölçekler 5li likert tipinde hazırlanmış ve 1-2-3-4-5 (kesinlikle katılmıyorum; katılmıyorum; kısmen katılıyorum; katılıyorum; kesinlikle katılıyorum) şeklinde oluşturulmuştur. 46 soruluk "Ekolojik Ayak İzi Farkındalık Ölçeği” ile oluşturulan sorular enerji (15 madde), ulaşım ve barınma ( 9 madde), atıklar ( 9 madde), gıda (8 madde) ve su tüketimi (5 madde) olmak üzere beş alt boyuttan şekillenmiştir.

Nicel veriler "Ekolojik Ayak İzi Farkındalık Ölçeği"(EAİFÖ) ile toplanarak 23.0 paket programı ile değerlendirilerek analiz edilmiştir. Veriler korelasyon analizi ve varyans analizleri ile değerlendirilmiştir.

\subsection{Güvenirlik Önlemleri}

EAİFÖ su tüketimi, enerji, ulașım, atıklar, barınma ve gıda alt boyutlarından oluşmaktadır. Ekolojik Ayak İzi (EAİ) toplam puanı: 0,87 olarak bulunmuş ve Cronbach's Alpha değerleri; Gıda boyutu için: 0,51, Ulaşım ve Barınma boyutunda 0,61, Enerji boyutu için: 0,86, Atıklar boyutu için: 0,62 ve Su tüketimi boyutu için: 0,57 olarak değerlendirilmiştir.

\subsection{Etik Konular}

"Mimarlık Fakültesi Öğrencilerinin Ekolojik Ayak İzi Farkındalık Düzeyi" başlıklı bu bilimsel çalışma için 
çalışma kapsamında anket sorularının uygulanması öncesinde SDÜ Mimarlık Fakültesi Dekanlık biriminden gerekli izinler alınmış ve bunun yanı sıra SDÜ Fen ve Mühendislik Bilimleri Etik Kurulunun 25.08.2020 tarihli ve 50/2 sayılı kararı ile Etik Kurul raporu da çalışmaya eklenmiştir.

\section{Bulgular}

\subsection{Demografik Özelliklere Göre Dağılım}

Tablo 1'de cinsiyet değişkenine göre \% 58,4 kadın ve \%41,6 erkek olarak görülmektedir. Tablo 2'de yaș değişkenine göre \% 51,5’i (18-20 yaş) ve \%48,5'i (21 ve üzeri yaş) olarak görülmektedir. Tablo 3'te bölüm değişkenine göre \%37,2 -Mimarlık-, \%34,6 -Şehir ve Bölge Planlama- ve \%28,2 -Peyzaj Mimarlığl- bölümü olarak bulunmuştur. Tablo 4'te sınıf değişkenine göre \%32,6'sı 1.Sinıf, \%22,2 (2.Sinıf); 23,8 3.Sinıf ve \%21,5 4.Sınıf olarak görülmüştür.

Tablo 1. Cinsiyet değişkeni dağılımı

\begin{tabular}{cccc}
\hline & & n & \% \\
\hline \multirow{3}{*}{ Cinsiyet } & Kadın & 253 & 58,4 \\
& Erkek & 180 & 41,6 \\
& Toplam & 433 & 100,0 \\
\hline
\end{tabular}

Tablo 2. Yaș değişkeni dağılımı

\begin{tabular}{cccc}
\hline & & $\mathbf{n}$ & $\mathbf{\%}$ \\
\hline \multirow{4}{*}{ Yaş } & 18-20 yaş & 223 & 51,5 \\
& 21 ve üzeri yaş & 210 & 48,5 \\
& Toplam & 433 & 100,0 \\
\hline
\end{tabular}

Tablo 3. Bölüm değișkeni dağılımı

\begin{tabular}{cccc}
\hline & & $\mathbf{n}$ & $\mathbf{\%}$ \\
\hline \multirow{4}{*}{ Bölümm } & Mimarlık & 161 & 37,2 \\
& Şehir ve Bölge & 150 & 34,6 \\
& Planlama & 122 & 28,2 \\
& Peyzaj Mimarlığı & 122 & 100,0 \\
\hline
\end{tabular}

Tablo 4. Sınıf değișkeni dağılımı

\begin{tabular}{cccc}
\hline & & $\mathbf{n}$ & $\mathbf{\%}$ \\
\hline \multirow{4}{*}{ Sinıf } & 1.Sinif & 141 & 32,6 \\
& 2.Sinıf & 96 & 22,2 \\
& 3.Sinif & 103 & 23,8 \\
& 4.Sinif & 93 & 21,5 \\
& Toplam & 433 & 100,0 \\
\hline
\end{tabular}

Tablo 5'te en uzun süre yașanılan yer değișkenine göre $\% 62,8$ il , \%27,3 ilçe, \%8,3 köy, \%1,6 kasaba olarak görülmüştür.

Tablo 5. En uzun süre yaşanılan yer değişkeni dağılımı

\begin{tabular}{cccc}
\hline & & $\mathbf{n}$ & $\mathbf{\%}$ \\
\hline & Köy & 36 & 8,3 \\
En Uzun Süre & Kasaba & 7 & 1,6 \\
Yaşanılan Yer & İlçe & 118 & 27,3 \\
& İl & 272 & 62,8 \\
& Toplam & 433 & 100,0 \\
\hline
\end{tabular}

\subsection{Ekolojik Ayak İzi (EAİ) Puanlarına Yönelik Bulgular}

Tablo 6'da EAİ boyutları ve toplam EAİ puanına göre cinsiyet değişkeni için t-testi analizi uygulanmıştır. Değerlendirmede $(\mathrm{p}<0,05$ anlamlılık düzeyi) esas alınarak ortalama düzeylere yönelik değerlendirme yapılmıştır.

EAİ (Enerji, Atık, Barınma, Ulaşım ve Gıda) alt boyutlarında ortaya çıkan puanların farklılığ -cinsiyet değişkenine- göre anlamlı bulunmuş $(p<0,05)$ ve su tüketimi boyutunda ortaya çıkan puanların farklılığ cinsiyet için anlamsız görülmüştür $(p>0,05)$.

EAİ puanlarında kız öğrencilerin almış oldukları puanların erkek öğrencilerden daha yüksek olduğu görülmektedir. Su tüketimi haricinde diğer boyutlarda kız öğrencilerin erkeklere göre anlamlı derecede EAİ farkındalığı yüksek olduğu görülmektedir.

Tablo 7'de EAİ boyutları ve toplam EAİ puanı için yaş değişkeni t-testi analizi uygulanmıştır. Anlamlılık düzeyi $(p<0,05)$ esas alınarak, ortalama düzeylere yönelik değerlendirme yapılmıştır. EAİ, yaş değişkenine göre tüm alt boyutlarda oluşan puanların farklılığı anlamsız ( $p>0,05)$ görülmüştür. 18-20 yaş aralığında EAİ puanları -21 ve üzeri- yaş grubunda bulunanlardan daha yüksek görülmüștür. Ekolojik bilinç düzeyinin -18-20 yaş- aralığında daha yüksek olduğu belirlenmiştir.

Tablo 8'de EAİ boyutları ve toplam EAİ puanına yönelik bölüm için ANOVA analizi uygulanmıştır. Analizde $(p<0,05)$ anlamlılık düzeyi esas alınarak ortalama düzeylere yönelik değerlendirme yapılmıştır.

EAİ puanları tüm boyutlarda puanların farklılığı bölüme göre anlamsız $(p>0,05)$ görülmüștür. EAI "gıda, ulaşım ve barınma" boyutunda PM bölümünün puanları diğer bölümlerden yüksektir. ŞBP bölümünde "enerji ve atık" boyutlarında ise diğer bölümlerden yüksek bulunmuștur. Ek olarak "su tüketimi” ŞBP bölümünde daha yüksek olduğu görülmektedir.

Tablo 9'da EAİ boyutlara ve toplam EAİ puanına yönelik "sınıf" için ANOVA analizi uygulanmıştır. Değerlendirmede $(p<0,05)$ anlamlılık düzeyi esas alınarak ortalama düzeylere yönelik değerlendirme yapılmıştır.

EAİ tüm boyutlarda puanların farklılığı "sınıf" için anlamsız (p>0,05) görülmüştür. EAİ (ulaşım ve barınma, enerji ile atık puanları) 1.sınıf öğrencileri için daha yüksek bulunmuş; "gıda" puanı 4.sınıf öğrencilerinde yüksek; "su tüketimi" puanı 2.sınıf öğrencilerinde yüksek olarak görülmüştür. 
Tablo 6. Cinsiyet değișkeni EAİ puanlar

\begin{tabular}{ccccccccc}
\hline & Cinsiyet & $\mathbf{N}$ & Ort & SS & F & t & df & p \\
\hline Ekolojik & Kadın & 253 & 3,7409 & 0,42336 & 7,102 & 4,202 & 431 & 0,000 \\
Ayak İzi & Erkek & 180 & 3,5468 & 0,53654 & & 4,040 & 327,113 & \\
\hline \multirow{2}{*}{ Gıda } & Kadın & 253 & 3,0970 & 0,49928 & 0,003 & 4,162 & 431 & 0,000 \\
& Erkek & 180 & 2,8971 & 0,48251 & & 4,186 & 393,423 & \\
\hline \multirow{2}{*}{ Ulaşım ve } & Kadın & 252 & 3,2330 & 0,49986 & 0,375 & 3,228 & 430 & 0,001 \\
Barınma & Erkek & 180 & 3,0716 & 0,52910 & & 3,198 & 372,126 & 431 \\
\hline \multirow{2}{*}{ Enerji } & Kadın & 253 & 4,0342 & 0,51618 & 8,317 & 4,458 & 4,000 \\
& Erkek & 180 & 3,7817 & 0,66158 & & 4,278 & 324,403 & \\
\hline \multirow{2}{*}{ Atık } & Kadın & 253 & 3,7338 & 0,57720 & 2,286 & 3,172 & 430 & 0,002 \\
& Erkek & 179 & 3,5219 & 0,81160 & & 2,998 & 300,966 & \\
\hline \multirow{2}{*}{ Su Tüketimi } & Kadın & 253 & 3,7725 & 0,68537 & 4,478 & 0,325 & 430 & 0,745 \\
& Erkek & 179 & 3,7464 & 0,98531 & & 0,307 & 296,206 \\
\hline
\end{tabular}

Tablo 7. Yaş değişkeni EAİ puanları

\begin{tabular}{|c|c|c|c|c|c|c|c|c|}
\hline & Yaş & $\mathbf{N}$ & Ort & SS & $\mathbf{F}$ & $T$ & df & $\mathbf{p}$ \\
\hline \multirow{2}{*}{$\begin{array}{c}\text { Ekolojik Ayak } \\
\text { İzi }\end{array}$} & $18-20$ & 223 & 3,6863 & 0,43010 & 6,153 & 1,162 & 431 & 0,246 \\
\hline & 21 ve üzeri & 210 & 3,6324 & 0,53256 & & 1,155 & 401,861 & \\
\hline \multirow{2}{*}{ Gida } & $18-20$ & 223 & 3,0260 & 0,50719 & 0,191 & 0,517 & 431 & 0,605 \\
\hline & 21 ve üzeri & 210 & 3,0010 & 0,49648 & & 0,518 & 430,350 & \\
\hline \multirow{2}{*}{$\begin{array}{l}\text { Ulaşım ve } \\
\text { Barınma }\end{array}$} & $18-20$ & 222 & 3,1996 & 0,49552 & 1,424 & 1,399 & 430 & 0,162 \\
\hline & 21 ve üzeri & 210 & 3,1299 & 0,53924 & & 1,396 & 421,756 & \\
\hline \multirow{2}{*}{ Enerji } & $18-20$ & 223 & 3,9659 & 0,52283 & 5,899 & 1,328 & 431 & 0,185 \\
\hline & 21 ve üzeri & 210 & 3,8902 & 0,65945 & & 1,319 & 398,278 & \\
\hline \multirow{2}{*}{ Atık } & $18-20$ & 223 & 3,6464 & 0,64753 & 1,894 & 0,011 & 430 & 0,991 \\
\hline & 21 ve üzeri & 209 & 3,6456 & 0,73651 & & 0,011 & 414,642 & \\
\hline \multirow{2}{*}{ Su Tüketimi } & $18-20$ & 223 & 3,7825 & 0,86050 & 0,862 & 0,543 & 430 & 0,587 \\
\hline & 21 ve üzeri & 209 & 3,7395 & 0,78038 & & 0,545 & 429,541 & \\
\hline
\end{tabular}

Tablo 8. Bölüme göre EAİ puanları

\begin{tabular}{|c|c|c|c|c|c|c|c|}
\hline & & $\mathbf{N}$ & Ort & SS & df & $\mathbf{F}$ & p \\
\hline \multirow{4}{*}{ Ekolojik Ayak İzi } & Mimarlık & 161 & 3,6320 & 0,50248 & 2 & 0,472 & 0,624 \\
\hline & Şehir ve Bölge Planlama & 150 & 3,6840 & 0,49192 & 430 & & \\
\hline & Peyzaj Mimarlığı & 122 & 3,6681 & 0,44521 & & & \\
\hline & Toplam & 433 & 3,6602 & 0,48270 & 432 & & \\
\hline \multirow{4}{*}{ Gida } & Mimarlık & 161 & 2,9973 & 0,54134 & 2 & 1,812 & 0,165 \\
\hline & Şehir ve Bölge Planlama & 150 & 2,9736 & 0,49190 & 430 & & \\
\hline & Peyzaj Mimarlığı & 122 & 3,0852 & 0,45313 & & & \\
\hline & Toplam & 433 & 3,0139 & 0,50160 & 432 & & \\
\hline \multirow{4}{*}{ Ulaşım ve Barınma } & Mimarlık & 161 & 3,1064 & 0,52809 & 2 & 2,974 & 0,052 \\
\hline & Şehir ve Bölge Planlama & 149 & 3,1557 & 0,51008 & 429 & & \\
\hline & Peyzaj Mimarlığı & 122 & 3,2562 & 0,50496 & & & \\
\hline & Toplam & 432 & 3,1657 & 0,51781 & 431 & & \\
\hline \multirow{4}{*}{ Enerji } & Mimarlık & 161 & 3,9018 & 0,63730 & 2 & 0,278 & 0,758 \\
\hline & Şehir ve Bölge Planlama & 150 & 3,9490 & 0,57851 & 430 & & \\
\hline & Peyzaj Mimarlığı & 122 & 3,9410 & 0,55408 & & & \\
\hline & Toplam & 433 & 3,9292 & 0,59355 & 432 & & \\
\hline \multirow{4}{*}{ Atık } & Mimarlık & 160 & 3,6607 & 0,71048 & 2 & 0,438 & 0,646 \\
\hline & Şehir ve Bölge Planlama & 150 & 3,6704 & 0,75737 & 429 & & \\
\hline & Peyzaj Mimarlığı & 122 & 3,5968 & 0,57329 & & & \\
\hline & Toplam & 432 & 3,6460 & 0,69120 & 431 & & \\
\hline \multirow{4}{*}{ Su Tüketimi } & Mimarlık & 160 & 3,7122 & 0,75231 & 2 & 1,805 & 0,166 \\
\hline & Şehir ve Bölge Planlama & 150 & 3,8643 & 0,95896 & 429 & & \\
\hline & Peyzaj Mimarlığı & 122 & 3,7004 & 0,71474 & & & \\
\hline & Toplam & 432 & 3,7617 & 0,82205 & 431 & & \\
\hline
\end{tabular}


Tablo 9. Sınıf değişkeni EAİ puanları

\begin{tabular}{|c|c|c|c|c|c|c|c|}
\hline & & $\mathbf{N}$ & Ort & SS & Df & $\mathbf{F}$ & $\mathbf{p}$ \\
\hline & 1.Sinıf & 141 & 3,7421 & 0,41588 & 3 & 2,273 & 0,080 \\
\hline & 2.Sinıf & 96 & 3,6383 & 0,48497 & 429 & & \\
\hline \multirow[t]{5}{*}{ Ekolojik Ayak İzi } & 3.Sinıf & 103 & 3,5879 & 0,54138 & & & \\
\hline & 4.Sinıf & 93 & 3,6386 & 0,49595 & & & \\
\hline & Toplam & 433 & 3,6602 & 0,48270 & 432 & & \\
\hline & 1.Sinıf & 141 & 3,0321 & 0,52188 & 3 & 0,356 & 0,785 \\
\hline & 2.Sinif & 96 & 2,9959 & 0,52302 & 429 & & \\
\hline \multirow[t]{5}{*}{ Gida } & 3.Sinıf & 103 & 2,9801 & 0,48248 & & & \\
\hline & 4.Sinıf & 93 & 3,0422 & 0,47275 & & & \\
\hline & Toplam & 433 & 3,0139 & 0,50160 & 432 & & \\
\hline & 1.Sinıf & 140 & 3,1954 & 0,52720 & 3 & 0,452 & 0,716 \\
\hline & 2.Sinif & 96 & 3,1195 & 0,53818 & 428 & & \\
\hline \multirow[t]{5}{*}{ Ulaşım ve Barınma } & 3.Sinıf & 103 & 3,1801 & 0,50591 & & & \\
\hline & 4.Sinif & 93 & 3,1528 & 0,49935 & & & \\
\hline & Toplam & 432 & 3,1657 & 0,51781 & 431 & & \\
\hline & 1.Sinıf & 141 & 4,0686 & 0,48097 & 3 & 4,758 & 0,003 \\
\hline & 2.Sinif & 96 & 3,9092 & 0,60084 & 429 & & \\
\hline \multirow[t]{5}{*}{ Enerji } & 3.Sinıf & 103 & 3,7898 & 0,70476 & & & \\
\hline & 4.Sinif & 93 & 3,8929 & 0,57056 & & & \\
\hline & Toplam & 433 & 3,9292 & 0,59355 & 432 & & \\
\hline & 1.Sinif & 141 & 3,7007 & 0,56112 & 3 & 0,593 & 0,620 \\
\hline & 2.Sinıf & 95 & 3,5953 & 0,75218 & 428 & & \\
\hline \multirow[t]{5}{*}{ Atık } & 3.Sinif & 103 & 3,6056 & 0,65013 & & & \\
\hline & 4.Sinif & 93 & 3,6595 & 0,83852 & & & \\
\hline & Toplam & 432 & 3,6460 & 0,69120 & 431 & & \\
\hline & 1.Sinif & 141 & 3,8067 & 0,96305 & 3 & 1,162 & 0,324 \\
\hline & 2.Sinif & 95 & 3,8547 & 0,69799 & 428 & & \\
\hline \multirow[t]{3}{*}{ Su Tüketimi } & 3.Sinıf & 103 & 3,6665 & 0,74962 & & & \\
\hline & 4.Sinıf & 93 & 3,7038 & 0,77978 & & & \\
\hline & Toplam & 432 & 3,7617 & 0,82205 & 431 & & \\
\hline
\end{tabular}

Tablo 10'da EAİ boyutları ve toplam EAİ puanına yönelik en uzun süre yaşanılan yere ilişkin ANOVA analizi uygulanmış; $(\mathrm{p}<0,05)$ anlamlılık düzeyi esas alınarak ortalama düzeylere yönelik değerlendirme yapılmıştır.

EAİ, tüm alt boyutlarda puanların farklılığı yaşanılan yere göre anlamsız(p>0,05) görülmüştür. İlde yaşayanların EAİ -enerji ve su tüketimi- puanları daha yüksek; kasabada yaşayanların -gıda ulaşım, barınmapuanları diğerlerinden yüksek olarak görülmüştür.

Tablo 11'de EAİ tüm boyutlarda bulunan korelasyon analizi değerlendirilmiştir. Boyutlar arasındaki pozitif ve negatif ilişkinin değerlendirilmesine yönelik olarak bu analiz yapılmış ve bunun sonucunda istatistiki yönde anlamlı $(\mathrm{p}<0,05)$ görülmüştür. Su tüketimi ile EAİ Gıda, Ulaşım ve Barınma, Enerji, Atık alt boyutlarında pozitif yönlü ilişki olduğu görülmektedir.

Tablo 12'de "gıda" için öğrencilerin verdikleri yanıtlar görülmektedir. Değerlendirme ortalama ve standart sapma değerlerine yönelik yorumlanmıştır. En yüksek puanın "Alışverişte ihtiyacımdan fazla gıdaya yönelik besin almamaya özen gösteririm." $(3,28 \pm 1,16)$ maddesinde görülmüştür. En düşük puan ise "Plastikle paketlenmiş işlenmiş gıdaları satın almamaya dikkat ederim" $(2,66 \pm 1,04)$ maddesinde görülmüştür. Diğer maddelerin değerleri şu şekildedir;
- Mevsimi dışında üretilen gıdaları tüketmeyi tercih etmem; 3,00 $\pm 0,886$

- Hayvansal gidalar yerine alternatif olarak sebze ve meyve ile beslenirim; 2,86 $\pm 1,052$

- Hazır ve pratik gidalarla beslenmeyi tercih ederim; 3,04 $\pm 0,902$

- Yerel ve mahalle pazarlarına gitmeyi tercih ederim; 3,19 $\pm 1,023$

- Gıda alış verişinde yabancı ürünleri almamaya dikkat ederim.2,88 $\pm 1,048$

- Beslenmede önceliğim organik tarım ürünleridir;3,16 $\pm 0,860$

Tablo 13'te "ulaşım ve barınma" için cevaplar bulunmaktadır. Değerlendirme ortalama ve standart sapma değerlerine yönelik yapılmıştır. En yüksek puan "Araç satın almak istersem doğa dostu yakıtlı olanları tercih ederim" $(4,04 \pm 0,98)$ maddesi; en düşük puan ise "Müstakil evlerin apartmanlara göre kullanım alanı daha fazladır ve daha çok doğaya zarar verdiğini düşünürüm" $(2,23 \pm 1,02)$ maddesi almıştır. Diğer maddeler şu şekildedir;

- Şehirlerarası ulaşımda doğa dostu yakıt kullanan ulaşım araçları ile yolculuk etmeyi tercih ederim $; 2,70 \pm 1,024$

- Araçlarla aşırı hız yapıldığında, yakıt tüketimi artar ve bu çevre için oldukça zararlıdır; $3,84 \pm 1,046$ 
- Yolda araç kullanırken freni az kullanarak sabit hızda gitmeyi tercih ederim.; 3,42 $\pm 1,101$

- Doğa dostu olduğu ve çevreyi kirletmediği düşüncesiyle bisiklet kullanmayı tercih ederim; 2,82 $\pm 1,082$

- Büyük evler doğada daha çok yer kapladığı için zararlıdır; 2,82 $\pm 1,122$
- Ekolojik olan ev eşyalarını satın almayı tercih ederim; 3,38 $\pm 1,029$

- Yaşadığım alanlarda ortak kullanım alanlarının daha çok, şahsi kullanım alanlarının daha az olmasına dikkat ederek düzenlerim;3,26 $\pm 1,0$

Tablo 10. En uzun süre yaşanılan yere göre EAİ puanları

\begin{tabular}{|c|c|c|c|c|c|c|c|}
\hline & & $\mathbf{N}$ & Ort & SS & df & $\mathbf{F}$ & p \\
\hline \multirow{5}{*}{ Ekolojik Ayak İzi } & Köy & 36 & 3,6651 & 0,55357 & 3 & 1,368 & 0,252 \\
\hline & Kasaba & 7 & 3,6533 & 0,43807 & 429 & & \\
\hline & İlçe & 118 & 3,5848 & 0,45919 & & & \\
\hline & İl & 272 & 3,6924 & 0,48275 & & & \\
\hline & Toplam & 433 & 3,6602 & 0,48270 & 432 & & \\
\hline \multirow{5}{*}{ Gida } & Köy & 36 & 3,1066 & 0,52126 & 3 & 0,648 & 0,585 \\
\hline & Kasaba & 7 & 3,1429 & 0,45887 & 429 & & \\
\hline & İlçe & 118 & 2,9928 & 0,49774 & & & \\
\hline & İl & 272 & 3,0074 & 0,50256 & & & \\
\hline & Toplam & 433 & 3,0139 & 0,50160 & 432 & & \\
\hline \multirow{5}{*}{$\begin{array}{l}\text { Ulaşım ve } \\
\text { Barınma }\end{array}$} & Köy & 36 & 3,2018 & 0,47804 & 3 & 1,434 & 0,232 \\
\hline & Kasaba & 7 & 3,4226 & 0,24583 & 428 & & \\
\hline & İlçe & 118 & 3,0974 & 0,50066 & & & \\
\hline & İl & 271 & 3,1840 & 0,53307 & & & \\
\hline & Toplam & 432 & 3,1657 & 0,51781 & 431 & & \\
\hline \multirow{5}{*}{ Enerji } & Köy & 36 & 3,8774 & 0,74884 & 3 & 0,950 & 0,416 \\
\hline & Kasaba & 7 & 3,7714 & 0,55758 & 429 & & \\
\hline & İlçe & 118 & 3,8720 & 0,58945 & & & \\
\hline & İl & 272 & 3,9649 & 0,57322 & & & \\
\hline & Toplam & 433 & 3,9292 & 0,59355 & 432 & & \\
\hline \multirow{5}{*}{ Atık } & Köy & 36 & 3,7739 & 0,93322 & 3 & 1,634 & 0,181 \\
\hline & Kasaba & 7 & 3,5714 & 0,50686 & 428 & & \\
\hline & İlçe & 118 & 3,5365 & 0,60681 & & & \\
\hline & İl & 271 & 3,6786 & 0,68982 & & & \\
\hline & Toplam & 432 & 3,6460 & 0,69120 & 431 & & \\
\hline \multirow{5}{*}{ Su Tüketimi } & Köy & 36 & 3,6528 & 0,68180 & 3 & 1,073 & 0,360 \\
\hline & Kasaba & 7 & 3,8571 & 0,89974 & 428 & & \\
\hline & İlçe & 118 & 3,6712 & 0,74994 & & & \\
\hline & İl & 271 & 3,8131 & 0,86528 & & & \\
\hline & Toplam & 432 & 3,7617 & 0,82205 & 431 & & \\
\hline
\end{tabular}

Tablo 11. EAİ puanları arasında korelasyon ilișkisi

\begin{tabular}{|c|c|c|c|c|c|c|}
\hline & & Su Tüketimi & Gida & $\begin{array}{c}\text { Ulaşım ve } \\
\text { Barınma }\end{array}$ & Enerji & $\begin{array}{c}\text { Ekolojik Ayak } \\
\text { İzi }\end{array}$ \\
\hline \multirow{3}{*}{ Su Tüketimi } & Korelasyon & 1 & $154^{* *}$ &, $278^{* *}$ & ,498** &, $402^{* *}$ \\
\hline & $\mathrm{P}$ & & 0,001 & 0,000 & 0,000 & 0,000 \\
\hline & $\mathrm{N}$ & 432 & 432 & 431 & 432 & 432 \\
\hline \multirow{3}{*}{ Gida } & Korelasyon & ,154** & 1 & $353^{* *}$ & ,291** & $245^{* *}$ \\
\hline & $\mathrm{P}$ & 0,001 & & 0,000 & 0,000 & 0,000 \\
\hline & $\mathrm{N}$ & 432 & 433 & 432 & 433 & 432 \\
\hline \multirow{3}{*}{ Ulaşım ve Barınma } & Korelasyon & $278^{* *}$ & ,353** & 1 &, $409^{* *}$ & ,318** \\
\hline & $\mathrm{P}$ & 0,000 & 0,000 & & 0,000 & 0,000 \\
\hline & $\mathrm{N}$ & 431 & 432 & 432 & 432 & 431 \\
\hline \multirow{3}{*}{ Enerji } & Korelasyon & $498^{* *}$ & $291^{* *}$ & $409^{* *}$ & 1 &, $537^{* *}$ \\
\hline & $\mathrm{P}$ & 0,000 & 0,000 & 0,000 & & 0,000 \\
\hline & $\mathrm{N}$ & 432 & 433 & 432 & 433 & 432 \\
\hline \multirow{3}{*}{ Ekolojik Ayak İzi } & Korelasyon &, $402^{* *}$ &, $245^{* *}$ & ,318** &, $537^{* *}$ & 1 \\
\hline & $\mathrm{P}$ & 0,000 & 0,000 & 0,000 & 0,000 & \\
\hline & $\mathrm{N}$ & 432 & 432 & 431 & 432 & 432 \\
\hline
\end{tabular}


Tablo 12. Gida boyutu cevaplar

\begin{tabular}{|l|l|c|c|c|}
\hline \multicolumn{1}{|c|}{ Boyut } & \multicolumn{1}{|c|}{ Maddeler } & N & Ort & SS \\
\hline \multirow{5}{*}{ Gıda } & Mevsimi dıșında üretilen gıdaları tüketmeyi tercih etmem. & 432 & 3,00 & 0,886 \\
\cline { 2 - 5 } & $\begin{array}{l}\text { Hayvansal gıdalar yerine alternatif olarak sebze ve meyve ile } \\
\text { beslenirim. }\end{array}$ & 433 & 2,86 & \multirow{2}{*}{1,052} \\
\cline { 2 - 5 } & Hazır ve pratik gıdalarla beslenmeyi tercih ederim. & 432 & 3,04 & 0,902 \\
\cline { 2 - 5 } & $\begin{array}{l}\text { Alışveriște ihtiyacımdan fazla gıdaya yönelik besin almamaya özen } \\
\text { gösteririm. }\end{array}$ & 429 & 3,28 & 1,161 \\
\cline { 2 - 5 } & Yerel ve mahalle pazarlarına gitmeyi tercih ederim. & 431 & 3,19 & 1,023 \\
\cline { 2 - 5 } & Gida alıș verișinde yabancı ürünleri almamaya dikkat ederim. & 427 & 2,88 & 1,048 \\
\cline { 2 - 5 } & Plastikle paketlenmiș işlenmiș gıdaları satın almamaya dikkat ederim. & 427 & 2,66 & 0,952 \\
\cline { 2 - 5 } & Beslenmede önceliğim organik tarım ürünleridir. & 432 & 3,16 & 0,860 \\
\hline
\end{tabular}

Tablo 13. Ulașım ve barınma cevapları

\begin{tabular}{|c|c|c|c|c|}
\hline Boyut & Maddeler & $\mathbf{N}$ & Ort & SS \\
\hline \multirow{9}{*}{ Ulaşım ve Barınma } & $\begin{array}{l}\text { Şehirlerarası ulaşımda doğa dostu yakıt kullanan ulaşım araçları ile } \\
\text { yolculuk etmeyi tercih ederim. }\end{array}$ & 424 & 2,70 & 1,024 \\
\hline & $\begin{array}{l}\text { Araçlarla aşırı hız yapıldığında, yakıt tüketimi artar ve bu çevre için } \\
\text { oldukça zararlıdır. }\end{array}$ & 429 & 3,84 & 1,046 \\
\hline & Araç satın almak istersem doğa dostu yakıtlı olanları tercih ederim. & 424 & 4,04 & 0,985 \\
\hline & $\begin{array}{l}\text { Yolda araç kullanırken freni az kullanarak sabit hızda gitmeyi tercih } \\
\text { ederim. }\end{array}$ & 418 & 3,42 & 1,101 \\
\hline & $\begin{array}{l}\text { Doğa dostu olduğu ve çevreyi kirletmediği düşüncesiyle bisiklet } \\
\text { kullanmayı tercih ederim. }\end{array}$ & 427 & 2,82 & 1,082 \\
\hline & Büyük evler doğada daha çok yer kapladığı için zararlıdır. & 430 & 2,82 & 1,122 \\
\hline & Ekolojik olan ev eşyalarını satın almayı tercih ederim. & 426 & 3,38 & 1,029 \\
\hline & $\begin{array}{l}\text { Yaşadığım alanlarda ortak kullanım alanlarının daha çok, şahsi kullanım } \\
\text { alanlarının daha az olmasına dikkat ederek düzenlerim. }\end{array}$ & 424 & 3,26 & 1,017 \\
\hline & $\begin{array}{l}\text { Müstakil evlerin apartmanlara göre kullanım alanı daha fazladır ve daha } \\
\text { çok doğaya zarar verdiğini düşünürüm. }\end{array}$ & 430 & 2,23 & 1,028 \\
\hline
\end{tabular}

Tablo 14'te "enerji" için cevaplar verilmiştir. Değerlendirme ortalama ve standart sapma değerlerine yönelik yapılmıştır. En yüksek puan "Yapıları güneş enerjisini göz önüne alarak uygun yerlere inşa etmek doğru bir yaklaşımdır" $(4,30 \pm 0,85)$ maddesi; en düşük puan ise "Elektrikli eşyaları (PC, TV, müzik çalar gibi) kullanmadığımda uyku modunda tutmak yerine kapatırım" $(3,49 \pm 1,19)$ maddesi olmuştur. Diğer maddeler şu şekildedir;

- Isınmak için temiz enerji kaynaklarını tercih ederim; 3,62 $\pm 0,959$

- Klima açıkken pencereleri kapatırım; $4,21 \pm 0,923$

- Kombi çalışırken pencereleri açmamaya özen

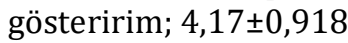

- Buzdolabını açtığımda kapağını kısa sürede

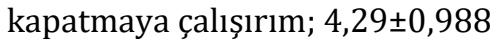

- Enerji tasarruflu beyaz eşya kullanırım; $3,92 \pm 0,940$

- Yaşadığım binada ısı yalıtımını önemser ve desteklerim; 4,13 $\pm 0,915$

- Aydınlatmada geleneksel ampule alternatif kompakt floresan ampul (CFL)- kullanmayı tercih ederim; $3,87 \pm 1,028$

- Teknolojik gereçleri (TV, PC gibi)kullandıktan sonra kapatırım; 3,94 $\pm 1,112$

- Çamaşır ve bulaşık makinesini dolu olarak çalıştırmaya özen gösteririm; 3,75 $\pm 1,092$

- Evde değilsem (uzun bir süre) kombi gibi

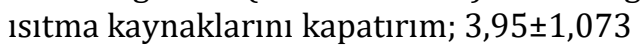

- $\quad$ Elektrikli eşyaları (PC, cep telefonu gibi) şarj

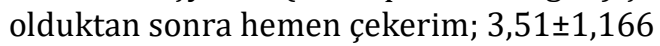

- Aydınlatmada gereksiz yere fazla aydınlatma elemanı kullanmam; 3,83 $\pm 0,978$

- Yenilenebilir enerji kaynaklarını (güneş enerjisi, jeotermal enerji, hidrojen vb.) kullanmayı tercih ederim; 3,97 $\pm 0,930$

Tablo 15'te "atıklar" için cevaplar bulunmaktadır. Değerlendirme ortalama ve standart sapma değerlerine yönelik yapılmıștır. En yüksek puan "Yiyeceğim kadar yemek pişirmeye ve hazırlamaya dikkat ederim" $(4,02 \pm 0,97)$ maddesi; en düșük puan ise "Alışverişte tek kullanımlık poşet yerine çok kullanımlı (çanta bez, file vb.) kullanırım" $(2,94 \pm 1,06)$ maddesidir. Diğer cevaplar şu şekildedir;

- Bozuk-eski elektrikli aletleri, akü ve pilleri geridönüşüme atarım.; 3,73 $\pm 1,005$

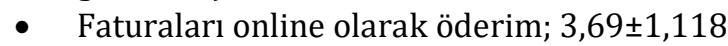

- Evsel atıklardan geri dönüştürülebilir olanları

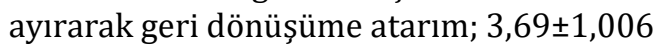

- Yemeklerden artan yiyecekleri çöpe atmam; $3,71 \pm 1,097$

- Ambalajları atmayarak onları farklı alanlarda ihtiyaca yönelik kullanmaya özen gösteririm; 3,53 $\pm 1,007$

- Tekrar şarj edilebilir pil kullanırım; 3,48 $\pm 1,095$

- Ambalaj atıklarını (cam, teneke, plastik, kağıt) ayırarak geridönüşüme kazandırırım; $3,84 \pm 0,931$ 
Tablo 16'da "su tüketimi" için cevaplar bulunmaktadır. Değerlendirme ortalama ve standart sapma değerlerine yönelik yapılmıştır. En yüksek puan "Bulaşık ve çamaşır makinesini dolu olarak çalıştırmaya özen gösteririm" $(3,97 \pm 0,94)$ maddesi; En az puan ise "Gerektiği kadar temizlik malzemesi kullanırım" $(3,64 \pm 1,05)$ maddesidir. Diğer cevaplar şu şekildedir;
- Ev temizlerken yıkamaktan ziyade silerim; $3,42 \pm 1,138$

- Çift basmalı tuvalet sifonları su tasarrufu açısından faydalıdır; $3,83 \pm 1,010$

- Duşta uzun süre kalmamaya dikkat eder, çeşmeyi gereksiz yere açmayarak (diş firçalama, traş olma vb.) su tasarrufuna dikkat ederim; 3,87 $\pm 1,041$

Tablo 14. Enerji boyutu cevapları

\begin{tabular}{|c|c|c|c|c|}
\hline Boyut & Maddeler & $\mathbf{N}$ & Ort & SS \\
\hline \multirow{15}{*}{ Enerji } & Isınmak için temiz enerji kaynaklarını tercih ederim. & 431 & 3,62 & 0,959 \\
\hline & Klima açlkken pencereleri kapatırım. & 431 & 4,21 & 0,923 \\
\hline & Kombi çalışırken pencereleri açmamaya özen gösteririm. & 430 & 4,17 & 0,918 \\
\hline & Buzdolabını açtığımda kapağını kısa sürede kapatmaya çalışırım. & 431 & 4,29 & 0,988 \\
\hline & Enerji tasarruflu beyaz eşya kullanırım. & 432 & 3,92 & 0,940 \\
\hline & Yaşadığım binada ısı yalıtımını önemser ve desteklerim. & 431 & 4,13 & 0,915 \\
\hline & $\begin{array}{l}\text { Aydınlatmada geleneksel ampule alternatif -kompakt floresan ampul } \\
\text { (CFL)- kullanmayı tercih ederim. }\end{array}$ & 433 & 3,87 & 1,028 \\
\hline & Teknolojik gereçleri (TV, PC gibi)kullandıktan sonra kapatırım. & 433 & 3,94 & 1,112 \\
\hline & Çamaşır ve bulașık makinesini dolu olarak çalıștırmaya özen gösteririm. & 432 & 3,75 & 1,092 \\
\hline & $\begin{array}{l}\begin{array}{l}\text { Evde değilsem (uzun bir süre) kombi gibi ısıtma kaynaklarını } \\
\text { kapatırım. }\end{array} \\
\end{array}$ & 432 & 3,95 & 1,073 \\
\hline & $\begin{array}{l}\text { Elektrikli eşyaları (PC, cep telefonu gibi) şarj olduktan sonra hemen } \\
\text { çekerim. }\end{array}$ & 432 & 3,51 & 1,166 \\
\hline & $\begin{array}{l}\text { Yapıları güneş enerjisini göz önüne alarak uygun yerlere inşa etmek } \\
\text { doğru bir yaklașımdır. }\end{array}$ & 430 & 4,30 & 0,856 \\
\hline & Aydınlatmada gereksiz yere fazla aydınlatma elemanı kullanmam. & 431 & 3,83 & 0,978 \\
\hline & $\begin{array}{l}\text { Yenilenebilir enerji kaynaklarını (güneş enerjisi, jeotermal enerji, } \\
\text { hidrojen vb.) kullanmayı tercih ederim. }\end{array}$ & 427 & 3,97 & 0,930 \\
\hline & $\begin{array}{l}\text { Elektrikli eşyaları (PC, TV, müzik çalar gibi) kullanmadığımda uyku } \\
\text { modunda tutmak yerine kapatırım. }\end{array}$ & 430 & 3,49 & 1,192 \\
\hline
\end{tabular}

Tablo 15. Atıklar için cevaplar

\begin{tabular}{|c|l|c|c|c|}
\hline Boyut & \multicolumn{1}{|c|}{ Maddeler } & N & Ort & \multicolumn{1}{|c|}{ SS } \\
\hline \multirow{5}{*}{ Atıklar } & Bozuk-eski elektrikli aletleri, akü ve pilleri geri dönüșüme atarım. & 430 & 3,73 & 1,005 \\
\cline { 2 - 5 } & Faturaları online olarak öderim. & 432 & 3,69 & 1,118 \\
\cline { 2 - 5 } & $\begin{array}{l}\text { Evsel atıklardan geri dönüştürülebilir olanları ayırarak geri dönüşüme } \\
\text { atarım. }\end{array}$ & 430 & 3,69 & 1,006 \\
\cline { 2 - 5 } & Yemeklerden artan yiyecekleri çöpe atmam. & 430 & 3,71 & 1,097 \\
\cline { 2 - 5 } & Yiyeceğim kadar yemek pişirmeye ve hazırlamaya dikkat ederim. & 431 & 4,02 & 0,974 \\
\cline { 2 - 5 } & $\begin{array}{l}\text { Alışverişte tek kullanımlı poşet yerine çok kullanımlı (çanta bez, file } \\
\text { vb.) kullanırım. }\end{array}$ & 432 & 2,94 & 1,062 \\
\cline { 2 - 5 } & $\begin{array}{l}\text { Ambalajları atmayarak onları farklı alanlarda ihtiyaca yönelik } \\
\text { kullanmaya özen gösteririm. }\end{array}$ & 432 & 3,53 & 1,007 \\
\cline { 2 - 5 } & Tekrar şarj edilebilir pil kullanırım. & 429 & 3,48 & 1,095 \\
\cline { 2 - 5 } & $\begin{array}{l}\text { Ambalaj atıklarını (cam, teneke, plastik, kâğıt) ayırarak geridönüşüme } \\
\text { kazandırırım. }\end{array}$ & 431 & 3,84 & 0,931 \\
\hline
\end{tabular}

Tablo 16. Su tüketimi cevapları

\begin{tabular}{|c|c|c|c|c|}
\hline Boyut & Maddeler & $\mathbf{N}$ & Ort & SS \\
\hline \multirow{5}{*}{ Su Tüketimi } & Ev temizlerken yıkamaktan ziyade silerim. & 431 & 3,42 & 1,138 \\
\hline & Gerektiği kadar temizlik malzemesi kullanırım. & 429 & 3,64 & 1,053 \\
\hline & Çift basmalı tuvalet sifonları su tasarrufu açısından faydalıdır. & 430 & 3,83 & 1,010 \\
\hline & Bulaşık ve çamaşır makinesini dolu olarak çalıştırmaya özen gösteririm. & 431 & 3,97 & 0,944 \\
\hline & $\begin{array}{l}\text { Duşta uzun süre kalmamaya dikkat eder, çeşmeyi gereksiz yere } \\
\text { açmayarak (diș firçalama, traș olma vb.) su tasarrufuna dikkat ederim. }\end{array}$ & 432 & 3,87 & 1,041 \\
\hline
\end{tabular}

\section{Sonuç ve Öneriler}

EAİ, kişiler tarafından tüketilen malzeme ve atık miktarını değerlendirmenin yalın bir anlatımıdır. $\mathrm{Bu}$ araştırmada SDÜ Mimarlık Fakültesi öğrencilerinde tüm boyutlarda EAİ puanlarının kız öğrencilerin erkek öğrencilerden daha yüksek olduğu bulunmuștur. Enerji boyutunda 4. Sınıf öğrencilerinin EAİ puanları daha yüksek olduğu görülmüştür. "Su tüketimi" boyutu ile EAİ, Gıda, Ulaşım ve Barınma, Enerji, Atık alt boyutlarında pozitif yönlü ilişki olduğu görülmektedir. 
Bu kapsamda çalışmada belirlenen sonuçlar şu şekildedir;

1. EAİ toplamı ile Gıda, Ulaşım ve Barınma, Enerji ve Atık alt boyutlarında puanların farklılığı "cinsiyet" için anlamlı $(\mathrm{p}<0,05)$ iken su tüketimi boyutunda cinsiyet değişkenine göre anlamsızdır ( $p>0,05)$. EAİ Gıda, Ulaşım ve Barınma, Enerji ve Atık boyutlarında kız öğrenciler erkek öğrencilerden daha yüksek puan almış ve su tüketimi boyutu dışında tüm boyutlar içinde anlamlı derecede kız öğrencilerin erkek öğrencilerden EAİ farkındalığı yüksek çıkmıştır.

2. EAİ toplamı ile tüm boyutlarda puanların farklılığı yaș değişkenine göre anlamsızdır $(p>0,05)$ olarak bulunmuştur. 18-20 yaş aralığında olan öğrenciler EAİ puanları, 21 ve üzeri yaş grubu öğrencilerinden yüksek olarak bulunmuştur.

3. EAİ tüm boyutlarda puanların farklılığı bölüm değişkenine göre anlamsız $(p>0,05)$ olarak bulunmuştur. EAİ gıda, ulaşım ve barınma boyutunda Peyzaj Mimarlığı bölümü öğrencileri için puanları diğer bölümlerden yüksek; enerji ve atık boyutlarında ise Şehir ve Bölge Planlama bölümü öğrencileri için diğer bölümlerden daha yüksek bulunmuștur.

4. EAİ tüm boyutlarda puanların farklılığı sınıf değişkenine göre anlamsız (p>0,05) olarak bulunmuştur. EAİ ulaşım ve barınma, enerji ile atık puanları 1.sınıf öğrencilerinde daha yüksek; gıda boyutunda 4.sınıf öğrencilerinde daha yüksek; su tüketimi boyutunda ise 2.sınıf öğrencilerinde daha yüksek olarak görülmüştür.

5. EAİ tüm boyutlarda puanların farklılığı en uzun süre yaşanılan yer değișkenine göre anlamsız ( $p>0,05)$ olarak bulunmuştur. İlde yaşam süren öğrencilerin EAİ "enerji ve su tüketimi" boyutunda daha yüksek; kasabada yaşam süren öğrencilerin "gıda, ulaşım ve barınma puanları diğerlerinden daha yüksek görülmüștür.

6. Korelasyon analizinde istatistiki olarak anlamlı $(\mathrm{p}<0,05)$ bulunmuş ve sonuçların su tüketimi ile EAİ tüm boyutlarda pozitif yönlü ilişki olduğu görülmüștür.

7. Gıda için değerlendirmede en yüksek puan "Alışveriște ihtiyacımdan fazla gıdaya yönelik besin almamaya özen gösteririm" $(3,28 \pm 1,16)$ maddesi iken en düşük puan "Plastikle paketlenmiş işlenmiş gıdaları satın almamaya dikkat ederim." $(2,66 \pm 1,04)$ maddesi olmuştur.

8. Ulaşım ve barınma için en yüksek puan "Araç satın almak istersem doğa dostu yakıtlı olanları tercih ederim." $(4,04 \pm 0,98)$ maddesi iken ; en düşük puan "Müstakil evlerin apartmanlara göre kullanım alanı daha fazladır ve daha çok doğaya zarar verdiğini düşünürüm" $(2,23 \pm 1,02)$ maddesi olmuştur.

9. Enerji için en yüksek puan "Yapıları güneş enerjisini göz önüne alarak uygun yerlere inşa etmek doğru bir yaklaşımdır." $(4,30 \pm 0,85)$ maddesi iken; en düşük puan ise "Elektrikli eşyaları (PC, TV, müzik çalar gibi) kullanmadığımda uyku modunda tutmak yerine kapatırım." $(3,49 \pm 1,19)$ maddesi olmuştur.

10. Atıklar için en yüksek puan "Yiyeceğim kadar yemek pişirmeye ve hazırlamaya dikkat ederim." $(4,02 \pm 0,97)$ maddesi iken; en düşük puan "Alışverişte tek kullanımlık poşet yerine çok kullanımlı (çanta bez, file vb.) kullanırım." $(2,94 \pm 1,06)$ maddesi olmuştur.

11. Su tüketimi için en yüksek puan "Bulaşık ve çamaşır makinesini dolu olarak çalıştırmaya özen gösteririm." $(3,97 \pm 0,94)$ maddesi iken; en düşük puan "Gerektiği kadar temizlik malzemesi kullanırım." $(3,64 \pm 1,05)$ maddesi olmuştur.

Elde edilen sonuçlara göre Peyzaj Mimarlığı, Mimarlık, Şehir ve Bölge Planlama bölümlerinin ekolojik ayak izi farkındalık değerleri birbirine çok yakın bulunmuştur. EAİ puanları barınma, ulaşım ve gıda boyutlarında Peyzaj Mimarlığı bölümü öğrencilerinde diğer bölüm öğrencilerinden yüksek olduğu; Şehir ve Bölge Planlama bölümü öğrencilerinde atık ve enerji boyutları alanında EAİ puanları diğer bölüm öğrencilerinden daha yüksek olduğu görülmüştür.

Doğanın ve doğal kaynakların tükendiği, canlıların yaşam alanlarının zamanla daha da kısıtlandığı ve hayatın giderek zorlaştığı dünyada ekolojik ayak izi farkındalığı çok büyük önem taşımaktadır. Yaşanılabilir bir dünya ve gelecek nesillere daha iyi bir yaşam alanı bırakabilmek için doğa odaklı çözümler üreterek yaşamak gerekmektedir.

Hayatlarımızı idame ettirirken bir yandan doğal kaynakları tüketiyor ve birçok atığı üretiyoruz. İnsanoğlunun dengeli ve sürdürülebilir bir yaşam sürmesi için dünyaya verdiği ekolojik baskıyı fark etmesi önemlidir. Dengeli bir sürdürülebilirlik anlayışı ile beraber doğa odaklı seçimler ve biyolojik çeșitliği göz önüne alan yaklaşımlarla doğanın devamlılığı sağlanabilir.

EAİ, yerel ve küresel anlamda tüketimin çevre ölçeğinde limiti hangi alanlarda ve nerelerde aşıldığını bildiren bir sürdürülebilirlik göstergesi olup; insanlığın ne ölçüde biyolojik kapasite tükettiğini ölçmektedir $[5,6,7]$. EAİ, bireylerin ve kuruluşların günlük eylemleri ile bu eylemlerle ilişkili çevresel etkiler arasında bir bağlantı oluşturmasına yardımcı olur [8]. Sürdürülebilirlik faaliyetlerinin kurumsallaşmasında yaşam boyu eğitim ve etkinlikler doğru yönde ilerlemeyi sağlar ve üniversiteler gibi eğitim kurumlarında tüm yaşamsal süreçleri izlemeye katkıda bulunur. EAİ konusunda olumlu tutum ve davranışları, EAİ azaltmak için ne yapmaları konusunda bilgi sahip olmaları anlamında onlara yol gösterebilir.

Ekolojik ayak izinin çevre eğitiminde bir eğitim aracı olarak kullanıldığı birçok çalışma vardır. Örnek bir araştırmada ekolojik ayak izinin öğretmen adaylarının 
dengeli sürdürülebilir bir yaşam hedefinde davranışlarını fark etmelerinde olumlu yönde etkili olduğunu ve tutumlarının geliștiğini göstermiștir [3].

Japonya'da yapılan bir çalışmada [9] EAİ'nin ekolojik sürdürülebilirliği sağlamada önemli ve etkili bir eğitim modeli olduğu görülmüștür. Ülkede yaşayanlara EAİ'yi azaltmaları konusunda web-tabanlı bireysel EAİ hesaplama aracı geliștirilmiş ve bu yolla ekolojik bir bilinç kazandırılmak istenmiştir [10].

Yerleşkeler için EAİ ölçümü konusunda yapılan araştırmalardan biri Kolorado Üniversitesinde yapılmış ve EAİ analizi yedi bileşenle (kullanım alanı, elektrik, ulaşım, doğal gaz tüketimi, gıda tüketimi, su) değerlendirilmiştir. EAİ puanları sırasıyla; elektrik, doğal gaz, ulaşım, su ve gida tüketimi yönünde olmuştur. Bu yolla üniversite ilk hedef olarak elektrik tasarrufuna gitme konusuna odaklamış ve yenilikçi çalışmaları bu yönde başlatmıştır[11].

Anlaşıldığı üzere EAİ bizlere yaşamsal sürdürülebilirlik hedefinde bir yol haritası çizmektedir. Bireysel ayak izi hesaplamadan, evsel ayak izi hesaplamaya, yerleşke ayak izi ve kentlerin hatta ülkelerin EAİ hesaplamada sürdürülebilir bir hayat için gerekli birçok parametre vardır. Hedefler koymada ve farkındalık oluşturmada önemli, geliştirici bir araçtır [12]. İnsan ve doğa ile ilişki kurmada köprü farklı bakış açılarına ve yollara ihtiyaç olduğu görülmektedir [13]. Başka bir perspektiften; modern eğitim öğretilerinin insan ve doğayı rekabet halinde göstermekte ve birlik değerinden uzaklaştırmaktadır. $\mathrm{Bu}$ durum da ister istemez öğretilerin günümüz insanını daha bencil ve rekabetçi bir modele sürüklemektedir. Yükseköğrenimler toplum yönünden mekanik metalar olarak algılanmakta olup; iş dünyasının teşvikiyle projeleri uyguladıkları için küresel şirketler karşısında pasifize olmakta ve entelektüel liderliklerini kaybetmektedirler. Bu durum beraberinde akademik kurumların birbiriyle olan bağlantısı ve diyaloğunu zayıflatmakta ve doğayı bir bütün olarak algılama perspektiflerini de yitirmelerine neden olmaktadır [14].

Farklı demografik bir yapıyla yapılan başka bir çalışmada ise büyük avmlere yakın olan, havaalanından uzak yerde yaşayan yüksek gelirli genç kişilerin "ulaşım" ayak izlerinin daha çok olduğu; şehre yakın yerlerde yaşayan, eğitimli ve yaşlı kişilerin daha çok "barınma" ayak izine sahip olduğu, daha kırsal bölgede yaşayan geliri yüksek, yaşlı ve bekâr erkeklerin ise daha çok "gıda" ayak izine sahip olduğu sonuçlarına ulaşılmıştır [15].

Ohio State Üniversitesinde atık üretimi ve ekolojik ayak izi bağlantısı üzerine yapılan çalışma sonucunda EAİ azaltmak için üniversitenin EAİ yüksek olduğu alanlarda ekolojik ve doğa odaklı stratejiler geliştirmesi gerektiği hedeflenmiştir [16].
Akdeniz Üniversitesi İİBF'de yapılan bir araştırmada çalışmaya katılan bireylerin ekolojik ayak izleri dünya ve ülkemiz ortalamasından daha yüksek çlkmıştır. Araştırmada gelir düzeyi ve yaş arttıkça ekolojik ayak izinin arttığ tespit edilmiş ve cinsiyete göre ekolojik ayak izlerinin anlamlı bir farklılık göstermediği bulunmuştur [17].

Gelişmiş olduğu düşünülen belli bir gelir seviyesinin üzerindeki ülkelerin EAİ etkisi oldukça fazladır. Çünkü sahip oldukları kaynaklardan daha fazlasını kullanarak EAİ oluşturmakta ve buda dolayısıyla tüm dünyayı etkilemektedir [18]. Yaşanılabilir ve sürdürülebilir bir dünya için doğa ile barıșık olmalı ve kuralları çerçevesinde yaşam ilkelerimizi oluşturmalıyız. EAİ azaltma bireylerin tercihlerinden başlayarak (örn: bir otomobile alırken ve çevreye daha az zarar veren doğa dostu bir model tercih etmesi; ulaşımda kısa yolculuklar için uçak yerine otobüs tercihi Jalışkanlıklar kazanılabilir [19, 20]. Sürdürülebilir bir yaşam felsefesi, eylemlerin örtüşmesi ile mümkün olacaktır. $\mathrm{Bu}$ konuda farkındalığın ve davranıșların kişilerin tutum ve değer yargılarının önemli olduğu bilinmelidir $[21,8]$.

Görüldüğü üzere ilgili literatür farklı alanlarda tarandığında ekolojik ayak izi birbirinden farklı alanlarda önemini göstermektedir. Bu doğrultuda yapılan bu çalışma ile Mimarlık Fakültesi bünyesinde eğitim gören Mimarlık, Şehir ve Bölge Planlama, Peyzaj Mimarlığı öğrencilerinin EAİ azaltma yönünde farkındalıklarını ve EAİ konusundaki eylemlerini belirlemek ilk aşama olmuştur. $\mathrm{Bu}$ çalışma, sürdürülebilir yaşam ilkelerinin özümsenmesinde ve uygulanmasında önemli bir role sahip olan Mimarlık Fakültesi öğrencilerine, kendi yaşamlarında dünya üzerinde bıraktıkları olumsuz etkileri görmeleri yönünde farkındalık kazandırmıştır. Dolayısıyla, ekolojik ayak izlerini azaltma konusundaki bilgilerini iş, sosyal ve özel yaşantılarında geleceğin dünyasına yansıtacakları için önemlidir.

Öğrencilerin ekolojik ayak izi farkındalıklarının arttırılabilmesi ve ilerleyen yaşamlarında daha bilinçli bireyler olabilmeleri için eğitim sistemi önemli yer tutmaktadır. İlkokuldan üniversiteye kadar ekoloji, çevre, doğa ve sürdürülebilirlik ile ilgili dersler müfredatta yer almalı; kamuoyu farkındalığı oluşturulmalıdır. Yaşanılabilir bir dünya ve gelecek nesiller için doğa ve çevre odaklı yaşamaya önem verilmelidir.

\section{Teşekkür}

Bu çalıșma, SDÜ BAP Koordinasyon Birimi tarafından 5103-YL1-17 numaralı proje kapsamında desteklenmiştir ve Süleyman Demirel Üniversitesi, Fen Bilimleri Enstitüsü Peyzaj Mimarlığı Anabilim Dalında, Destan SEÇME tarafından, Dr. Öğr. Üyesi Şehriban ERASLAN danışmanlığında tamamlanan "Ekolojik Ayak İzi Farkındalığı: SDÜ Mimarlık Fakültesi Öğrencileri Örneği” başlıklı yüksek lisans tezinden üretilmiştir. 


\section{Etik Beyanı}

Çalışma kapsamında anket sorularının uygulanması öncesinde Mimarlı Fakültesi Dekanllk biriminden gerekli izinler alınmış ve bunun yanısıra "Mimarlık Fakültesi Öğrencilerinin Ekolojik Ayak İzi Farkındalık Düzeyi" başlıklı bu bilimsel çalışma için SDÜ Fen ve Mühendislik Bilimleri Etik Kurulunun 25.08.2020 tarihli ve 50/2 sayılı kararı ile Etik Kurul raporu da alınmıştır.

\section{Kaynakça}

[1] Ökmen, M., (2010). Mekan-Ekosistem-ÇevreEkoloji-Çevrebilim: Kavramsal Tartışma, Çevre Sorunları Üzerine Güncel Yazılar. Edit, U. Yıldırım, Beta Basım, İstanbul, 12-15.

[2] Schaller, D., (1999). Our Footprints-They're All Over the Place. Newsletter of the Utah Society for Enviromental Education, 9 (4).

[3] Keleș, Ö., (2007). Sürdürülebilir yaşama yönelik çevre eğitimi aracı olarak ekolojik ayak izinin kullanılması ve değerlendirilmesi. Doktora tezi, Gazi Üniversitesi, Eğitim Bilimleri Enstitüsü, 202s, Ankara.

[4] Coşkun, I., (2013). Sınıf öğretmeni adaylarının ekolojik ayak izi farkındalık düzeylerinin belirlenmesi. Gazi Üniversitesi, Eğitim Bilimleri Enstitüsü, Yüksek Lisans Tezi, 104s, Ankara.

[5] Wackernagel, M., Rees, W. (1996). Our ecological footprint reducing human impact on the Earth. Canada: New Society Publishers.

[6] Lenzen, M., Murray, S. A. (2001). A modified ecological footprint method and its application to Australia. Ecological economics, 37(2), 229-255.

[7] Kitzes, J., Wackernagel, M. (2009). Answers to common questions in ecological footprint accounting. Ecological Indicators, 9(4), 812-817.

[8] Güngör, H. (2019). Bir okul öncesi eğitim kurumunda ekolojik ayak izi uygulamaları ile sürdürülebilir yaşam firsatlarının geliştirilmesi. Pamukkale Üniversitesi, Eğitim Bilimleri Enstitüsü, Doktora Tezi. 254s,Denizli.

[9] Wada, Y., Izumi, K., \& Mashiba, T. (2007). Development of a web-based personal ecological footprint calculator fort he Japanese. International Ecological Footprint Conference, 8$10^{\text {th }}$ May, Cardiff.

[10] Yıldız, E., (2014). Fen ve teknoloji öğretmen adaylarının ekolojik ayak izi farkındalık düzeylerinin belirlenmesi ve değerlendirilmesi. Gazi Üniversitesi, Fen Bilimleri Enstitüsü, Yüksek Lisans Tezi, 222s, Ankara.
[11] Wright, P. E., and Drossman, H., 2002. The Ecological Footprint of The Colorado College: An Examination of Sustainability. Environmental Science. 5 (1), 23.

[12] Anderle, K., 2002. Integrating Life Cycle Analysis and Ecological Footprint Calculator to Foster Sustainable Behaviors. MS Thesis, University of North Texas, 111p,Texas.

[13] Zhao, S., Li, Z., and Li, W., 2005. A Modified Method of Ecological Footprint Calculation and Its Application. Ecological Modelling, 185 (1), 65 75.

[14] Rees, E. W., 2003. Impeding Sustainability? The Ecological Footprint of Higher Education. Planning for Higher Education, 31 (3), 88-89.

[15] Ryu, H. C., 2005. Modeling the per Capita Ecological Footprint for Dallas County, Texas: Examining Demographic, Environmental Value, Land-Use, and Spatial Influences. Ph.D Thesis, Texas A\&M University, 211p, Texas.

[16] Janis, A. J., 2007. Quantifying the Ecological Footprint of the Ohio State University. Ph.D Thesis. The Ohio State University.

[17] Akılll, H., Kemahl,, F., Okudan, K., Polat, F., 2008. Ekolojik ayak izinin kavramsal içeriği ve Akdeniz Üniversitesi İktisadi ve İdari Bilimler Fakültesi'nde bireysel ekolojik ayak izi hesaplaması. Akdeniz İktisadi ve İdari Bilimler Fakültesi Dergisi, (15), 1-25.

[18] Kaypak, Ş., 2013. Ekolojik ayak izinden çevre barışına bakış. Türk Bilimsel Derlemeler Dergisi, 6(1), 154-159.

[19] Walker, P (2011). Cycle like the Danes to cut carbon emissions, says study. https://www.theguardian.com/environment/2 011/dec/12/cycle-like-danes-cutemissions. Erişim Tarihi: 08.05.2014.

[20] Ekolojist (2017). Ekolojik ayak izi nasıl küçültülür? http://ekolojist.net/ekolojik-ayakizinasil-kucultulur/ Erişim Tarihi: 07.06.2019.

[21] Erten, S. (2005). Okul öncesi öğretmen adaylarında çevre dostu davranışların araştırılması. Hacettepe Üniversitesi Eğitim Fakültesi Dergisi, 28(28), 91-100. 